\title{
DOMNIEMANIE PRAWDZIWOŚCI DEKLARACJI PODATKOWEJ I JEGO ZNACZENIE DOWODOWE
}

I. Domniemanie jest konstrukcją stosowaną w różnych dziedzinach prawa - zarówno tam, gdzie normy prawne regulują stosunki społeczne pomiędzy równymi sobie podmiotami, jak i w sferze, w której relacja prawna łącząca objęte nią strony jest oparta na podległości kompetencji (jedna strona stosunku prawnego jest podporządkowana drugiej). Jednocześnie nie ma wątpliwości co do tego, że sam termin „domniemanie” jest niejednorodny i może być różnie rozumiany. Ustawodawca, czy to kształtując, czy to dopuszczając domniemanie, nie zawsze posługuje się bowiem tym określeniem dla opisania istoty wspomnianego zjawiska. Niekiedy w przepisach ustanawiających konstrukcję domniemania wprost operuje się tą nazwą. Tak jest w szczególności w regulacji prawnej zawartej w art. $85 \S 1$ Kodeksu rodzinnego i opiekuńczego ${ }^{1}$. W myśl tego przepisu domniemywa się, że ojcem dziecka jest ten, kto obcował z matką dziecka nie dawniej niż w trzechsetnym, a nie później niż w sto osiemdziesiątym pierwszym dniu przed urodzeniem się dziecka, albo ten, kto był dawcą komórki rozrodczej w przypadku dziecka urodzonego w wyniku dawstwa partnerskiego w procedurze medycznie wspomaganej prokreacji. Podobnie, zgodnie z art. 7 Kodeksu cywilnego ${ }^{2}$, jeżeli ustawa uzależnia skutki prawne od dobrej lub złej wiary, domniemywa się istnienie dobrej wiary.

Niejako w opozycji do tych przypadków można lokować sytuacje, gdy prawodawca rzeczywiście konstruuje domniemanie, nie posługując się jednak tym określeniem w tekście prawnym. Jest tak w szczególności na obszarze prawa karnego - w myśl art. $5 \S 1$ Kodeksu postępowania karnego ${ }^{3}$ oskarżonego uważa się za niewinnego, dopóki jego wina nie zostanie udowodniona i stwierdzona prawomocnym wyrokiem. W podobny, „ukryty” sposób wyrażono domniemanie w art. $76 \S 1$ Kodeksu postępowania administracyjnego ${ }^{4}$. Stanowi on, że dokumenty urzędowe sporządzone w przepisanej formie przez

\footnotetext{
${ }^{1}$ Ustawa z 25 lutego 1964 r. - Kodeks rodzinny i opiekuńczy, t.jedn.: Dz. U. 2019, poz. 2086 (dalej jako: k.r.o.).

${ }^{2}$ Ustawa z 23 kwietnia 1964 r. - Kodeks cywilny, t.jedn.: Dz. U. 2019, poz. 1145 (dalej jako: k.c.).

${ }^{3}$ Ustawa z 6 czerwca 1997 r. - Kodeks postępowania karnego, t.jedn.: Dz. U. 2020, poz. 30 (dalej jako: k.p.k.).

${ }^{4}$ Ustawa z 14 czerwca 1960 r. - Kodeks postępowania administracyjnego, t.jedn.: Dz. U. 2020, poz. 256 (dalej jako: k.p.a.).
} 
powołane do tego organy państwowe w ich zakresie działania stanowią dowód tego, co zostało w nich urzędowo stwierdzone.

Wreszcie, warto zauważyć sytuacje, w których prawodawca nie tworzy konstrukcji prawnej domniemania jako normatywnie regulowanej operacji myślowej. Jednocześnie jednak dopuszcza on odwoływanie się do tego typu rozumowania w procesie stosowania przepisów prawa. Klasycznym tego przykładem jest dyrektywa wynikająca z art. 231 Kodeksu postępowania cywilnego ${ }^{5}$. W myśl tego przepisu sąd może uznać za ustalone fakty majace istotne znaczenie dla rozstrzygnięcia sprawy, jeżeli wniosek taki można wyprowadzić $\mathrm{z}$ innych ustalonych faktów (domniemanie faktyczne).

W świetle dotychczas przedstawionych tez nie ma wątpliwości co do tego, że domniemania pozostają w ścisłym związku z materią o fundamentalnym znaczeniu w każdej dziedzinie prawa, tzn. z powinnością udowadniania faktów mających znaczenie prawne, ponieważ rodzą skutki prawne. Dotyczy to zarówno domniemań faktycznych, jak i prawnych (regulowanych przez prawo). Zasada jest bowiem to, że następstwa zastosowania normy prawnej nie moga być wiązane z faktami nieudowodnionymi. Brak udowodnienia danej okoliczności wywołuje zaś dla danego podmiotu ujemne konsekwencje prawne, przejawiające się tym, że nie powstają skutki prawne właściwe wykazaniu danego faktu ${ }^{6}$. Niekiedy, na zasadzie wyjątku, ustawodawca pozwala natomiast uznać określoną okoliczność za pewna, mimo że nie została ona wykazana. Dotyczy to przykładowo faktów powszechnie znanych czy z urzędu wiadomych podmiotowi stosującemu prawo ${ }^{7}$. W tej grupie przypadków należy też sytuować domniemania. Ich zastosowanie, czy to z tego powodu, że ustawodawca je wyraźnie ukształtował (jako domniemania prawne), czy to przez wzgląd na to, iż są one dopuszczalne (bo niesprzeczne z prawem jako domniemania faktyczne), sprawia, że powstają sytuacje, z którymi wiążą się określone skutki prawne dla adresata normy prawnej, występujace bez potrzeby udowodnienia danego faktu ${ }^{8}$. Domniemanie staje się więc swoistym surogatem udowodnienia - trwałym lub niemającym takiego waloru, w zależności od tego, czy jest ono nieusuwalne, czy też nie spełnia tej cechy.

Mówiąc o domniemaniu, przede wszystkim należy wskazać na to, że opiera się ono na swoistym rachunku prawdopodobieństwa następstwa faktów ${ }^{9}$. Sprowadza się on do założenia, że jeśli nastapił jeden fakt, to potencjalnie możliwe, ale nie pewne jest zaistnienie faktu drugiego. Nie można bowiem a priori wykluczyć zakłócenia normalnego porządku rzeczy i tego, że po fakcie A nie wystąpi fakt $\mathrm{B}^{10}$. W związku z tym zdarza się, że domniemanie jest

${ }^{5}$ Ustawa z 17 listopada 1964 r. Kodeks postępowania cywilnego, t.jedn.: Dz. U. 2019, poz. 1460 (dalej jako: k.p.c.).

6 Nowacki (1976): 15.

7 Taką sytuację ustawodawca wskazał m.in. w art. $187 \S 3$ ustawy z 29 sierpnia 1997 r. Ordynacja podatkowa, t.jedn.: Dz. U. 2019, poz. 900. Stanowi on, że fakty powszechnie znane oraz fakty znane organowi podatkowemu z urzędu nie wymagają dowodu. Fakty znane organowi podatkowemu z urzędu należy jednak zakomunikować stronie.

8 Zob. Nowacki (1976): 15.

${ }^{9}$ Kunicki (1969): 7.

${ }^{10}$ Kunicki (1969): 7. 
charakteryzowane jako pewne powzięte z góry, typowe wyobrażenie, oparte na nabytej wiedzy albo znajomości każdego przedmiotu lub zjawiska, tkwiącej $\mathrm{w}$ podmiocie poznajacym ${ }^{11}$. Adresatem normy prawnej zawierajacej domniemanie jest natomiast podmiot uprawniony do prowadzenia postępowania, którego istotny fragment stanowi postępowanie dowodowe $\mathrm{e}^{12}$.

W swojej postaci, określanej jako domniemanie faktyczne, jest ono fakultatywną (gdyż zależną od woli prowadzącego proces rozumowania) metodą dowodzenia (operacją myślowa). Polega ona na tym, że z faktu niewatpliwego - niespornego (podstawy domniemania) wyprowadza się wnioski co do faktu domniemanego ${ }^{13}$. Jak już wcześniej wspomniano, dokonanie tego zależy od stopnia prawdopodobieństwa związku zależności pomiędzy tymi faktami, ocenianego przez podmiot prowadzacy proces myślowy. Jest on „mierzony” zasadami doświadczenia życiowego - praktyki dnia codziennego. Do prezentowanej reguły wnioskowania można się zaś odwołać wyłącznie w odniesieniu do zdarzeń, stanów czy przedmiotów, których istnienia lub nieistnienia nie można sprawdzić doświadczalnie lub wydedukować na mocy praw logicznego wynikania z innych okoliczności ${ }^{14}$.

Z kolei domniemanie prawne w największym uproszczeniu można scharakteryzować jako rozumowanie oparte na domniemaniu, nakazane na podstawie przepisu prawnego. W tym przypadku wspomniana operacja myślowa podmiotu stosującego prawo nie jest efektem jego wyboru, natomiast stanowi konsekwencję nakazu ustawowego, wyrażonego w przepisie. Ponadto w przypadku domniemania prawnego - inaczej niż w odniesieniu do domniemań faktycznych - nie wnioskuje się o jednym fakcie $\mathrm{z}$ innego faktu. Istotą domniemania tego typu jest natomiast wyprowadzanie z określonego, niewątpliwego faktu tezy dotyczącej prawa (faktu, z którego są wywodzone skutki prawne, prawa lub stosunku prawnego). To norma prawna, wiążąc podmiot stosujący prawo, rozstrzyga więc o występowaniu faktu prawotwórczego, prawa lub stosunku prawnego na podstawie innego faktu pozostajacego w związku ze stanem domniemanym. Tym samym prezentowana postać domniemania nie jest regułą dowodzenia, pozostajaca w sferze prawa procesowego, a przestrzenia jego funkcjonowania jest prawo materialne ${ }^{15}$. Działa ono tak, że w przepisie kształtującym domniemanie nie rozstrzyga się wprost o istnieniu faktu prawotwórczego lub o stosunku prawnym. Z woli prawodawcy odbywa się to natomiast w sposób pośredni i niestanowczy. W konsekwencji prawo lub stosunek prawny, jako zjawisko domniemane, staja się pewne dopiero w wyniku bierności lub braku przeciwdowodu przedstawionego przez podmiot, przeciwko któremu działa domniemanie ${ }^{16}$.

11 Jurewicz (2009): 25.

12 Zob. Patryas (2011): 14-15.

13 Tym samym istotą domniemania faktycznego jest wnioskowanie o jednym fakcie z innego faktu. Przejawia się ono wyprowadzaniem wniosku co do zaistnienia jednego faktu (faktu domniemanego) z innego faktu (faktu pewnego), stanowiącego podstawę domniemania - swoisty fundament (punkt odniesienia), na którym kształtuje się domniemanie (fakt domniemany).

${ }^{14}$ Gelger (1962): 47.

15 Kunicki (1969): 15.

16 Kunicki (1969): 13-14. 
W tym kontekście trafne jest upatrywanie w domniemaniu prawnym czynnika oddziałującego na ciężar dowodu ${ }^{17}$. Jednocześnie - przez wzgląd na materialnoprawną sferę, w której funkcjonuje ten typ domniemania - służy ono ochronie praw podmiotowych, a także zapewnieniu ładu oraz stabilności w sytuacjach niepewnych i wątpliwych ${ }^{18}$. Już sama daleko posunięta trudność lub niemożność przeprowadzenia dowodu na okoliczność zaistnienia faktu prawotwórczego może być bowiem legislacyjną przesłanką ukształtowania domniemania prawnego ${ }^{19}$.

II. Prawo podmiotowe, do którego nawiązuje się, prezentując sens operowania konstrukcja prawną domniemania w jego aspekcie prawnym, jest pojęciem charakterystycznym dla prawa cywilnego. Oznacza ono prawna możliwość postępowania w określony sposób, przyznaną podmiotowi prawa w normie prawnej, czyli zgodnie z treścią prawa ${ }^{20}$. Tym samym prawo podmiotowe pozostaje w sferze stworzonej przez ustawodawcę możności działania, uprawnienia określonego podmiotu i roszczenia, będącego jego konsekwencją. Wynika z niego prawna możliwość domagania się od innych określonego zachowania, majaca swoje podstawy w normie prawnej.

Swoistym odpowiednikiem prawa podmiotowego w prawie administracyjnym jest publiczne prawo podmiotowe. Pojęcie to definiuje się jako roszczenie majace normatywne podstawy, kierowane do państwa lub wspólnoty samorzadowej. Jego istota sprowadza się do domagania się określonego, pozytywnego zachowania adresata, odpowiadającego interesowi prawnemu żądającego. Ponadto treścia publicznego prawa podmiotowego jest roszczenie o brak ingerencji państwa albo wspólnoty samorządowej w prawnie określone sfery wolności uprawnionego podmiotu ${ }^{21}$. Dlatego jeżeli tylko istnieją ku temu wyraźne, prawne podstawy, przysługuje ono każdemu obywatelowi w celu zapewnienia ochrony oraz bezpieczeństwa prawnego ${ }^{22}$. Ponadto w doktrynie prawa administracyjnego daje się zauważyć przekonanie o istnieniu także publicznych praw podmiotowych państwa. Są nimi roszczenia tego podmiotu, kierowane do poszczególnych jednostek, o wykonanie przez nie obowiązków publicznoprawnych wynikających z mocy prawa. Jako odrębną kategorię wspomnianych praw wskazuje się natomiast roszczenia o wykonanie obowiązków publicznoprawnych, obciążających je na podstawie władczej działalności administracji publicznej (np. powinności z tytułu udzielonej koncesji) ${ }^{23}$.

Fundamentalną odmiennością prawa podatkowego w stosunku do prawa administracyjnego jest to, że w doktrynie prawa podatkowego, a także w praktyce stosowania jego przepisów nie operuje się pojęciem publicznego prawa podmiotowego. Trafnie kwestię tę wyartykułował Wojewódzki Sąd Admini-

\footnotetext{
17 Morawski (1981): 92.

18 Kunicki (1969): 15.

19 Zob. Grzybowski (1985): 303.

${ }^{20}$ Zob. Grzybowski (1985): $111 \mathrm{n}$.

21 Jakimowicz (2002): 218 oraz 254-262. Zob. także Masternak-Kubiak (2017): 237.

22 Tomaszewska (2012): 117.

23 Jakimowicz (2001): $59 \mathrm{n}$.
} 
stracyjny w Warszawie, zwracając uwagę na okoliczność, że charakteru publicznego prawa podmiotowego nie ma jeden z wydatków, klasyfikowanych jako koszt uzyskania przychodu, wskazany w art. 23 ust. 1 pkt 38 ustawy o podatku dochodowym od osób fizycznych. Nie jest więc tak, że od woli podatnika (jego wyboru) zależy, czy pomniejszy przychód o ten koszt. Wspomniana operacja jest natomiast powinnością podmiotu obowiązanego z tytułu podat$\mathrm{ku}^{24}$. To zaś sprawia, że nie sposób twierdzić, że podatnikowi w stosunku do państwa przysługuje roszczenie o uznanie jego wydatku za koszt uzyskania przychodu w podatku dochodowym.

Pojęciem, które ma podstawowe znaczenie w prawie podatkowym, jest podatkowy stan faktyczny. Dzieje się tak nie tylko przez wzgląd na dorobek doktryny tej dziedziny prawa, ale przede wszystkim z uwagi na ukształtowanie regulacji prawnej zawartej w Konstytucji $\mathrm{RP}^{25}$, a także w aktach ogólnego i szczególnego prawa podatkowego. Jak wynika z art. 217 ustawy zasadniczej, nakładanie podatków, innych danin publicznych, określanie podmiotów, przedmiotów opodatkowania i stawek podatkowych, a także zasad przyznawania ulg i umorzeń oraz kategorii podmiotów zwolnionych od podatków następuje w drodze ustawy. Swoistym uzupełnieniem i rozwinięciem tej dyrektywy są zaś unormowania zawarte w art. 5 i 6 Ordynacji podatkowej ${ }^{26}$. Wynika z nich, że podatek jest świadczeniem pieniężnym o cechach wskazanych w art. 6 Ord. podat., wynikającym z ustawy podatkowej. Do zaistnienia powinności podatkowej dochodzi zaś w ten sposób, że ma miejsce zdarzenie określone w ustawie podatkowej, powodujące powstanie obowiązu podatkowego ${ }^{27}$. Następnie może natomiast dojść do konkretyzacji obowiązku podatkowego, skutkiem czego jest przekształcenie się obowiązku podatkowego w zobowiązanie podatkowe ${ }^{28}$.

Zaprezentowany model powstawania powinności podatkowej sprawia, że podmioty obowiązane z tytułu podatku wstępuja w określone, zaprogramowane przez ustawodawcę, „gotowe” stosunki podatkowoprawne, łaczące je z państwem lub gminą ${ }^{29}$. Charakteryzuja się one tym, że podczas ich nawiązywania nie ma znaczenia element woli, czy to podatnika, czy to organu podatkowego. Dodatkowo dla powstawania powinności podatkowej charakterystyczne jest to, że dopiero zaistnienie określonego stanu faktycznego (realizacja zachowania, zdefiniowanego w ustawie) otwiera droge do wydania konstytutywnego lub deklaratoryjnego rozstrzygnięcia w sprawie podatkowej. Tym samym ewentualna decyzja podatkowa jest swoistą reakcją organu na zdarzenie, które już wystapiło. To zaś sprawia, że model działania organu stosujacego prawo podatkowe jest zasadniczo odmienny od rozstrzygania na

${ }^{24}$ Wyrok WSA w Warszawie z 5 marca 2013 r., III SA/Wa 2334/12, Lex nr 1321547. Rozstrzygnięcie zawarte w tym judykacie zostało zaaprobowane przez NSA, który oddalił skargę kasacyjną na to orzeczenie nieostateczne. Por. wyrok NSA z 28 sierpnia 2015 r., II FSK 1803/13, Lex nr 1801169.

${ }^{25}$ Konstytucja Rzeczypospolitej Polskiej z 2 kwietnia 1997 r., Dz. U. Nr 78, poz. 483 ze zm.

${ }^{26}$ Ustawa z 29 sierpnia 1997 r. Ordynacja podatkowa, t.jedn.: Dz. U. 2019, poz. 900 (dalej jako: Ord. podat.).

27 Por. art. 4 Ord. podat.

28 Por. art. 5 Ord. podat.

29 Mastalski (2019): 226. 
podstawie przepisów prawa administracyjnego. Jest tak, ponieważ w prawie administracyjnym, w większości przypadków, reguluje się stany mające nastapić w przyszłości. Inaczej niż w prawie podatkowym stan faktyczny (zachowanie podmiotu administrowanego) jest więc następczy w stosunku do rozstrzygnięcia organu, a prawo jest jednym z czynników kształtowania tego przyszłego stanu ${ }^{30}$.

Jak się wydaje, z tych właśnie powodów w prawie podatkowym nie można mówić o publicznym prawie podmiotowym jako roszczeniu (uprawnieniu) strony stosunku prawnego, chronionym poprzez domniemanie prawne. Punktem odniesienia domniemań jest natomiast powinność podatkowa, powstała $\mathrm{w}$ następstwie urzeczywistnienia przez podatnika podatkowego stanu faktycznego. Zastosowanie tej konstrukcji przez ustawodawcę ułatwia ustalenie lub określenie treści powinności podatkowej, co następuje w efekcie analizy zachowania zrealizowanego przez podmiot obowiązany z tytułu podatku. To zaś usprawnia wymiar i pobór daniny publicznej przy zastosowaniu regulacji prawnej z zakresu zarówno ogólnego, jak i szczególnego prawa podatkowego ${ }^{31}$.

III. Wśród domniemań stanowiących element regulacji podatkowoprawnej wyjątkowe miejsce zajmuje domniemanie prawdziwości deklaracji podatkowej. W swojej postaci, właściwej ogólnemu prawu podatkowemu, zostało ono ukształtowane w art. $21 \S 2$ i $§ 5$ Ord. podat. W przepisach tych ustawodawca sformułował prawne założenie prawdziwości informacji zawartych w deklaracji podatkowej będaccej dla organu podatkowego źródłem informacji o podmiocie i przedmiocie opodatkowania, a także o wysokości podstawy opodatkowania ${ }^{32}$. Jeżeli bowiem zobowiązanie podatkowe powstaje z mocy doręczenia decyzji konstytutywnej, co do zasady kwotę tej skonkretyzowanej powinności podatkowej ustala się zgodnie z danymi zawartymi w deklaracji, chyba że przepisy szczególne przewidują inny sposób ustalenia wysokości zobowiąania podatkowego albo w toku postępowania podatkowego stwierdzono, że dane zawarte w deklaracji, mogace mieć wpływ na wysokość zobowiązania podatkowego, sa niezgodne ze stanem faktycznym ${ }^{33}$.

Z kolei w myśl art. $21 \S 2$ Ord. podat., jeśli w przepisach prawa podatkowego nakłada się na podatnika obowiązek złożenia deklaracji, a zobowiązanie podatkowe powstaje $\mathrm{z}$ mocy prawa, tj. w sposób określony w art. $21 \S 1$ pkt 1 tej ustawy, podatek wykazany w deklaracji jest danina do zapłaty. Tym samym w ogólnym prawie podatkowym ustawodawca sformułował domnie-

30 Mastalski (2019): 28.

31 Zob. w szczególności art. 62b § 2 Ord. podat., w którym prawodawca ustanowił domniemanie pochodzenia wpłaty ze środków podatnika, jeżeli podatek został uiszczony przez inną osobę niż podmiot obowiązany z tytułu podatku, a treść dowodu zapłaty nie budzi wątpliwości co do przeznaczenia zapłaty na zobowiązanie podatnika. Por. także regulację z zakresu szczególnego prawa podatkowego - art. 2 ust. 6 ustawy z 26 lipca 1991 r. o podatku dochodowym od osób fizycznych, t.jedn.: Dz. U. 2019, poz. 1387. Przewidziano w nim, że w razie wątpliwości co do przychodów podatnika, w braku przeciwnego dowodu przyjmuje się, że pochodzą one z czynności, które mogą być przedmiotem prawnie skutecznej umowy.

32 Zob. Brzeziński (2005): 15.

33 Zob. art. $21 \S 5$ Ord. podat. 
manie prawdziwości zadeklarowanego zobowiąania podatkowego - zgodności jego kwoty z wartością skonkretyzowanej powinności podatkowej, powstałej równocześnie z obowiązkiem podatkowym, na skutek zaistnienia zdarzenia, z którym ustawodawca wiąże ten efekt.

Do konstrukcji domniemania związanego ze złożoną deklaracją podatkową odniesiono się także w przepisach szczególnego prawa podatkowego ${ }^{34}$. Jak się wydaje, regulacje te po części są refleksem, uzupełnieniem unormowania zawartego w Ordynacji podatkowej. Przez wzgląd na znaczenie fiskalne poszczególnych danin publicznych na pierwszy plan w tym zakresie wysuwa się regulacja prawna zawarta w ustawie o podatku od towarów i usług. Stanowi ona, że zobowiązanie podatkowe, kwotę zwrotu różnicy podatku, kwotę zwrotu podatku naliczonego lub różnicy podatku, o której mowa w art. 87 ust. 1 ustawy o podatku od towarów i usług, przyjmuje się w kwocie wynikającej z deklaracji podatkowej, chyba że organ podatkowy określi je w innej wysokości ${ }^{35}$. W ten sposób domniemanie prawdziwości zadeklarowanego zobowiązania podatkowego zostało rozciagnięte na nadwyżkę naliczonego podatku od towarów i usług nad kwotą podatku należnego.

Zapewnianie ładu i stabilności w sytuacjach niepewnych, właściwe domniemaniu prawnemu, ma swoją konsekwencję dowodowa. Jak już bowiem wcześniej artykułowano, prawo lub stosunek prawny, jako zjawisko domniemane, stają się pewne dopiero w wyniku bierności lub braku przeciwdowodu, przedstawionego przez podmiot, przeciwko któremu działa domniemanie ${ }^{36}$. Tym samym swoistym dopełnieniem domniemań prawnych zwiąanych z treścią złożonej deklaracji podatkowej są unormowania procesowe, dotyczące powinności dowodzenia. W prawie podatkowym zostały one wyrażone w art. 122 Ord. podat., a rozwinięte i skonkretyzowane w art. $187 \S 1$ tej ustawy. Zgodnie z tą regulacją prawną w toku postępowania organy podatkowe podejmują wszelkie niezbędne działania w celu dokładnego wyjaśnienia stanu faktycznego oraz załatwienia sprawy w postępowaniu podatkowym ${ }^{37}$. To organ podatkowy jest też zobowiązany zebrać i w sposób wyczerpujacy rozpatrzyć cały materiał dowodowy ${ }^{38}$. W konsekwencji podatnik jako strona stosunku podatkowoprawnego, słabsza niż podmiot uprawniony z tytułu podatku $^{39}$, uzyskuje instrument ochrony swoich praw w postaci domniemania

${ }^{34}$ Zob. przykładowo art. 8 ust. 1 i ust. 1a ustawy z 28 lipca 1983 r. o podatku od spadków i darowizn, t.jedn.: Dz. U. 2019, poz. 1813, zawierający domniemanie prawdziwości wartości podstawy opodatkowania zadeklarowanej przez podatnika. Zob. także art. 19 ust. 1 ustawy o podatku dochodowym od osób fizycznych. W przepisie tym ustawodawca ukształtował domniemanie prawdziwości wartości zbywanej nieruchomości, praw majątkowych albo innych rzeczy, wyrażonej w ich cenie określonej w umowie - dla celów opodatkowania dochodu.

${ }^{35}$ Art. 99 ust. 12 ustawy z 11 marca 2004 r. o podatku od towarów i usług, t.jedn.: Dz. U. 2020, poz. 106.

${ }^{36}$ Kunicki (1969): 13-14.

37 Art. 122 Ord. podat.

38 Art. $187 \S 1$ Ord. podat.

39 Dzieje się tak, ponieważ stosunek podatkowoprawny, podobnie jak stosunek administracyjnoprawny, jest relacją klasyfikowaną jako stosunek podległości kompetencji. 
prawnego, połączonego z powinnością dowodzenia, co do zasady ciążącą na administracji podatkowej ${ }^{40}$.

W przypadku gdy zobowiązanie podatkowe powstaje z mocy doręczenia ustalającej decyzji podatkowej, wsparcie dla podatnika przejawia się przyjęciem przez ustawodawcę założenia, że dane zawarte w deklaracji podatkowej są zgodne z prawem. Jeżeli natomiast organ podatkowy podaje je w watpliwość, powinność wykazania swoich racji (w szczególności innego niż zadeklarowany kształtu przedmiotu opodatkowania czy wartości podstawy opodatkowania) spoczywa na administracji podatkowej. Z kolei jeżeli konkretyzacja powinności podatkowej następuje z mocy samego prawa, zakłada się, że kwota wykazana w deklaracji podatkowej jest zgodna z rzeczywistą wartością zobowiązania podatkowego, powstałą w tej wysokości na skutek urzeczywistnienia przez podatnika wszystkich elementów podatkowego stanu faktycznego. Powinność (ciężar) ewentualnego obalenia tego domniemania jest zaś domena administracji podatkowej.

IV. Na tle tak ukształtowanych domniemań prawnych związanych ze złożeniem deklaracji podatkowej powstaje problem stosunku do tej konstrukcji normatywnej $\mathrm{w}$ praktyce stosowania przepisów prawa podatkowego. W tym zakresie istotne jest nie tylko uwzględnianie domniemań jako instytucji prawa materialnego, ale i honorowanie ich procesowego następstwa, w postaci dyspozycji art. 122 oraz $187 \S 1$ Ord. podat.

Jak się wydaje, nie do pogodzenia z art. $21 \S 2$ Ord. podat., a także ze wspomnianymi wcześniej przepisami procesowymi zawartymi w tej samej ustawie, jest swoiste dzielenie podatkowego stanu faktycznego na dwie części i wyróżnianie w jego ramach elementów, które ma wykazać organ podatkowy oraz składowych normy podatkowoprawnej, których zaistnienie powinien udowodnić podatnik. Klasycznym przykładem takiej postawy jest oczekiwanie, że koszty uzyskania przychodu jako element podatkowego stanu faktycznego, pomniejszający przychód i powodujący powstanie dochodu podatkowego, powinien wykazać podatnik ${ }^{41}$. Jak stwierdził w jednym ze swoich judykatów Wojewódzki Sąd Administracyjny w Krakowie, jeżeli organ podatkowy zakwestionował dany wydatek jako koszt uzyskania przychodu, to ciężar dowodu i inicjatywa w wskazywaniu środków dowodowych przechodzi na podmiot obo-

${ }^{40}$ Do wyjątków należą sytuacje, w których ciężar dowodu spoczywa na podatniku, czy szerzej: na podmiocie obowiązanym z tytułu podatku. W takiej sytuacji konieczne jest wyraźne, ustawowe uregulowanie takiego stanu. Zob. w szczególności art. $25 \mathrm{~g}$ ust. 1 ustawy o podatku dochodowym od osób fizycznych. Stanowi on, że w toku postępowania podatkowego albo w toku kontroli celno-skarbowej w przedmiocie opodatkowania przychodów nieznajdujaccych pokrycia w ujawnionych źródłach, albo pochodzących ze źródeł nieujawnionych ciężar dowodu w zakresie wykazania przychodów (dochodów) opodatkowanych lub przychodów (dochodów) nieopodatkowanych stanowiących pokrycie wydatku spoczywa na podatniku.

41 W nauce prawa podatkowego taką tezę stawia Hanusz (2006: 205), artykułując, że zgodnie z ogólnymi założeniami podatków typu dochodowego, aby zaliczyć dany wydatek do kosztów uzyskania przychodów, podatnik, a nie organ podatkowy powinien przedstawić źródła dowodowe lub wskazać środki dowodowe pozwalające uzyskać informacje wskazujące na fakt, że dany wydatek został poniesiony w celu osiagnięcia przychodu. 
wiązany z tytułu podatku. Wtedy też zasada prawdy obiektywnej, wyrażona w art. 122 i art. $187 \S 1$ Ord. podat., doznaje ograniczenia, polegającego na tym, iż w dążeniu do ustalenia rzeczywistego stanu faktycznego obowiązek współdziałania z organami podatkowymi spoczywa na podatniku, który winien poszukiwać środków dowodowych na poparcie swoich twierdzeń pod rygorem ujemnych skutków materialnych w płaszczyźnie oceny dowodowej ${ }^{42}$.

Do podobnej konstatacji, tyle że w odniesieniu do zwolnień podatkowych, doszedł Wojewódzki Sąd Administracyjny w Gdańsku. Stwierdził on, że korzystanie ze zwolnienia podatkowego nie jest obowiąkiem podatnika, lecz jego uprawnieniem. Jeżeli zaś podmiot ten chce skorzystać z prawa w postaci zwolnienia podatkowego, to tym samym na nim spoczywa ciężar wykazania spełnienia warunków wymaganych przez ustawodawcę. Zasadą jest bowiem to, że każdy, kto z określonych faktów wyprowadza dla siebie konsekwencje prawne, obowiązany jest fakty te udowodnić ${ }^{43}$.

Zaprezentowane zapatrywania pozostają w oczywistej opozycji nie tylko $\mathrm{w}$ odniesieniu do dorobku nauki, dotyczącego istoty domniemania prawnego oraz podatkowego stanu faktycznego, ale i - a może nawet przede wszystkim wobec dyspozycji wielokrotnie już powoływanych przepisów: art. $21 \S 2$ oraz art. 122 i 187 § 1 Ord. podat. Należy z całą mocą podkreślić, że - jak już wcześniej wskazywano - podatnik, realizując podatkowy stan faktyczny, wstępuje w „gotowy”, „zaprogramowany” przez ustawodawcę stosunek podatkowoprawny, z mocy samego prawa kształtowany przez całą treść normy podatkowoprawnej, a zatem także przez koszty uzyskania przychodu (w podatkach dochodowych) oraz przez zwolnienia podatkowe.

Odwołanie się do tych elementów konstrukcji podatku, co do zasady nie jest przestrzenia stosowania opcji podatkowej (wyboru podatkowego) ${ }^{44}$, koszty podatkowe zaś, zwolnienia i ulgi podatkowe, a także odliczenie naliczonego podatku od towarów i usług są elementami konstrukcji podatku, które z mocy samego prawa determinują wysokość zobowiązania podatkowego. Oznacza to w szczególności, że stan faktyczny kosztu, zwolnienia podatkowego czy redukcji należnego podatku od towarów i usług o kwotę podatku naliczonego stanowi element podatkowego stanu faktycznego kształtującego taka, a nie inna wysokość zobowiązania podatkowego. W konsekwencji „obiektem domniemania prawnego", związanego ze złożeniem deklaracji podatkowej zawierającej samoobliczenie podatku, jest cała powinność podatkowa, w tym także te jej elementy determinowane przez koszty uzyskania, zwolnienia podatkowe oraz odliczenie naliczonego podatku od wartości dodanej. W tej sytuacji oczekiwanie, że podmiot obowiązany z tytułu podatku będzie wykazywał spełnienie „korzystnych” dla siebie elementów podatkowego stanu faktycznego, nie ma uzasadnienia prawnego.

${ }^{42}$ Wyrok WSA w Krakowie z 11 czerwca 2008 r., I SA/Kr 462/08, Lex nr 478668.

${ }^{43}$ Wyrok WSA w Gdańsku z 17 kwietnia 2018 r., I SA/Gd 176/18, Lex nr 2494217.

${ }^{44}$ Więcej na temat opcji podatkowych (wyborów podatkowych) zob. Nita (2007): 57-63. Co do kwestii obligatoryjności zwolnień i ulg podatkowych zob. Morawski (2009): 261. 
Postawa organu podatkowego, przejawiajacca się jego „pasywnością dowodowa" i oczekiwaniem od podmiotu obowiąanego z tytułu podatku dowodzenia realizacji elementów podatkowego stanu faktycznego, wpływajacych na redukcję jego obciążenia podatkowego - stanowi naruszenie praw podatnika chronionego przez domniemania prawne, związane z treścią złożonej deklaracji podatkowej. Takie działanie administracji podatkowej świadczą też o faktycznym przenoszeniu na grunt prawa podatkowego oraz postępowania podatkowego regulacji prawnej, wynikającej z art. 6 k.c., stanowiącego, że ciężar udowodnienia faktu spoczywa na osobie, która z niego wywodzi skutki prawne ${ }^{45}$, uzupełnionej o dyspozycję art. 232 zd. 1 k.p.c. ${ }^{46}$ Wynika z niego, że strony są obowiązane wskazywać dowody dla stwierdzenia faktów, z których wywodzą skutki prawne.

Warto zauważyć, iż w żadnym akcie prawa podatkowego ustawodawca nie odsyła do stosowania czy do odpowiedniego stosowania wspomnianych przepisów prawa cywilnego. Z żadnego źródła prawa powszechnie obowiąującego w Rzeczypospolitej Polskiej nie wynika też, że w art. 6 k.c. oraz art. 232 k.p.c. prawodawca ustanawia jakaśs uniwersalna, „ponaddyscyplinarną” zasadę właściwą całemu prawu. Jednocześnie domniemanie prawdziwości deklaracji podatkowej oraz procesowa zasada prawdy obiektywnej (materialnej) wyrażona w art. 122 Ord. podat. sprawiaja, że negując treść dokumentu, jakim jest deklaracja podatkowa, to organ podatkowy jest obowiązany prowadzić dowód, także wtedy gdy dotyczy on czynników wpływających na redukcję obciążenia podatkowego podmiotu obowiązanego z tytułu podatku ${ }^{47}$. Jego bierność, wyrażająca się brakiem przeciwdowodu, sprawia zaś, że pewne staje się zobowiązanie podatkowe określone w deklaracji podatkowej lub informacje, na podstawie których nastapi jego wymiar w konstytutywnej decyzji podatkowej. Dlatego na aprobatę zasługuje zapatrywanie, że w prawie podatkowym nie znajduje zastosowania cywilistyczna reguła ciężaru dowodu ${ }^{48}$. Obalając domniemanie prawdziwości deklaracji podatkowej, także w zakresie wykazanej kwoty naliczonego podatku od towarów i usług, to organ podatkowy jest natomiast władny ustalić prawdę materialna. Powinien on to czynić, stosując wszelkie, obiektywnie możliwe w danych okolicznościach i legalne środki dowodowe ${ }^{49}$.

W tym kontekście warto zauważyć, że na stronie postępowania podatkowego, korzystajacej z domniemania prawnego ukształtowanego w art. 21 $\S 2$ i 5 Ord. podat., nie ciąży generalny obowiązek współdziałania z organem

45 Jest to materialny ciężar dowodu.

${ }^{46} \mathrm{~W}$ przepisie tym ukształtowano na potrzeby postępowania cywilnego formalny ciężar dowodu.

${ }^{47}$ Jak wskazują Brzeziński i Masternak (2004: 57), poddając krytyce tezę o zmieniającym się ciężarze dowodu, uprawnienia i obowiązki przysługujące organom spełniającym określone działania nie mogą przysługiwać adresatom tych działań, a uprawnienia i obowiązki podmiotu administrowanego nie mogą zostać przeniesione na organ podatkowy.

48 Por. wyrok WSA w Lublinie z 4 marca 2009 r., I SA/Lu 618/08, Lex nr 497192, oraz wyrok WSA w Gliwicach z 23 stycznia 2015 r., III SA/Gl 953/14, Lex nr 1678745.

${ }^{49}$ Wyrok WSA w Gliwicach z 18 lipca 2019 r., I SA/Gl 448/19, Lex nr 2703302. 
podatkowym w trakcie toczącego się postepowania podatkowego ${ }^{50}$. Co do zasady aktywność podmiotu obowiązanego w trakcie tej procedury jest natomiast prawem $^{51}$. Jego gwarancję ustawodawca zawarł w art. $123 \S 1$ Ord. podat. Stanowi on, że organy podatkowe są obowiązane zapewnić stronom czynny udział w każdym stadium postępowania, a przed wydaniem decyzji umożliwić im wypowiedzenie się co do zebranych dowodów i materiałów oraz zgłoszonych żądań. Ponadto w dalszych regulacjach zawartych w Ordynacji podatkowej ustawodawca skonkretyzował wspomnianą gwarancję procesowa. Istotne znaczenie w tym zakresie ma w szczególności unormowanie, zgodnie z którym strona powinna być zawiadomiona o miejscu i terminie przeprowadzenia dowodu z zeznań świadków, opinii biegłych lub oględzin przynajmniej na siedem dni przed terminem. Ma ona prawo brać udział w przeprowadzaniu dowodu, może zadawać pytania świadkom i biegłym oraz składać wyjaśnienia ${ }^{52}$. Ponadto okoliczność faktyczna może być uznana za udowodnioną dopiero wtedy, gdy strona miała możliwość wypowiedzenia się co do przeprowadzonych dowodów ${ }^{53}$, a - co do zasady - przed wydaniem decyzji organ podatkowy wyznacza jej siedmiodniowy termin do wypowiedzenia się w sprawie zebranego materiału dowodowego ${ }^{54}$.

Biorąc pod uwagę regulację prawną z zakresu ogólnego oraz szczególnego prawa podatkowego, należy wskazać, że powinność współdziałania podmiotu obowiąanego z tytułu podatku z organem podatkowym ma jedynie ograniczony, „szczątkowy” charakter. Nie ulega wątpliwości, że jest ona konsekwencja obciążenia podatnika różnego rodzaju instrumentalnymi obowiązkami podatkowymi ${ }^{55}$. Skoro ustawodawca nakłada na wspomniany podmiot tego rodzaju powinności, nie ma wątpliwości, że podatnik powinien udostępniać organowi podatkowemu „efekt” spełnienia instrumentalnego obowiąku podatkowego w postaci księgi podatkowej, deklaracji czy faktury. Tym samym wspiera on administrację podatkową w powinności ustalenia prawdy obiektywnej i w ewentualnym obaleniu domniemań prawnych, związanych ze złożeniem deklaracji podatkowej.

${ }^{50} \mathrm{Na}$ marginesie warto zauważyć, że w tym zakresie polski akt ogólnego prawa podatkowego w istotny sposób różni się chociażby od jego niemieckiego odpowiednika. Zgodnie z niemiecką Ordynacją podatkową strona postępowania jest bowiem zobowiązana do współdziałania z organem podatkowym przy ustalaniu stanu faktycznego. Przejawia się to dostarczaniem kompleksowych i rzetelnych informacji o okolicznościach istotnych dla sprawy, a także przedstawianiem znanych stronie dowodów. Zob. § 90 niemieckiej Ord. podat. (Abgabenordnung) - ustawa z 16 marca 1976 r. Abgabenordnung (BGBl. I S. 3866; 2003 I S; BStBl I S. 1056).

51 Zob. Mariański (2009): 128.

52 Art. 190 Ord. podat.

${ }^{53}$ Art. 192 Ord. podat.

54 Art. $200 \S 1$ Ord. podat.

55 Są to obowiązki podatkowe pomocnicze wobec podstawowej powinności uiszczenia należności podatkowej, umożliwiające ustalenie lub określenie wysokości zobowiązania podatkowego w prawidłowej wysokości. Zalicza się do nich w szczególności: prowadzenie dokumentacji podatkowej (ksiag podatkowych, czy kasy rejestrującej), wystawianie faktur i rachunków, a także przechowywanie oryginałów i kopii tych dokumentów, składanie deklaracji podatkowych. 
Nie ulega także wątpliwości to, że podatnik jest obowiązany udzielać wyjaśnień organowi podatkowemu ${ }^{56}$. Już jednak składanie zeznań jako przejaw aktywności procesowej tego podmiotu, która - w przeciwieństwie do dokonywania wyjaśnień - ma znaczenie dowodowe, jest uzależnione od zgody przesłuchiwanego ${ }^{57}$. W ten sposób ustawodawca chroni prawa podmiotu obowiązanego z tytułu podatku, będace konsekwencją sformułowania domniemań prawdziwości deklaracji podatkowej. Istotne jest bowiem to, aby podatnik, zeznając w charakterze strony, nie przyczynił się do usunięcia korzystnych dla siebie efektów istnienia domniemań prawnych.

Z tego względu trudno o akceptację wykorzystywania instytucji procesowej wezwań do wymuszania aktywności strony biernej stosunku podatkowoprawnego w postępowaniu podatkowym. W myśl wcześniej już powoływanego art. $155 \S 1$ Ord. podat. organ jest władny zwracać się do strony lub innej osoby o przedłożenie dokumentów lub dokonanie określonej czynności osobiście, przez pełnomocnika lub na piśmie, w tym także w formie dokumentu elektronicznego, jeżeli jest to niezbędne do wyjaśnienia stanu faktycznego lub rozstrzygnięcia sprawy. Dokonanie tego jest jednak możliwe tylko wtedy, gdy w polskim systemie prawnym istnieją unormowania materialnoprawne, z których wynika powinność posiadania określonego dokumentu i okazywania go administracji podatkowej na jej wezwanie lub obowiązek podejmowania określonej czynności na żądanie podmiotu uprawnionego z tytułu podatku. Sięganie do tej części dyspozycji art. $155 \S 1$ Ord. podat. bez spełnienia wspomnianych warunków stanowi przejaw nadużycia prawa przez organ podatkowy. Może ono też być uznane za niezgodne z prawem motywowanie podatnika do świadczenia swoistej pomocy w obalaniu domniemań prawnych prawdziwości deklaracji podatkowej. Skoro bowiem wspomniany podmiot, chroniąc się przed tym efektem, może odmówić składania zeznań, nie sposób zaakceptować skłaniania go do współdziałania z organem podatkowym podczas ustalania prawdy obiektywnej przy wykorzystaniu innych środków dowodowych niż zeznania strony.

V. Domniemania prawdziwości deklaracji podatkowej, ukształtowane w przepisach ogólnego oraz szczególnego prawa podatkowego, sa instrumentem ochrony podatnika jako słabszej niż organ podatkowy strony stosunku podatkowoprawnego, klasyfikowanego w nauce prawa jako relacja podległości kompetencji. Dzieje się tak, ponieważ „obiektem domniemania” staje się prawdziwość twierdzeń sformułowanych przez podmiot obowiązany z tytułu podat$\mathrm{ku} \mathrm{w}$ jego deklaracji podatkowej. Tym samym to administracja podatkowa powinna być dowodowo aktywna, podając w wątpliwość treść wspomnianego dokumentu złożonego przez podatnika. Jego czynna postawa w postępowaniu podatkowym i przyczynianie się do ustalania rzeczywistej treści zaistniałego stanu faktycznego co do zasady jest zaś prawem strony postępowania. Korzystając z niego, może się ona przyczynić do ustalenia okoliczności, czy do zgro-

56 Por. art. $155 \S 1$ Ord. podat.

57 Art. 199 Ord. podat. 
madzenia dowodów, które potwierdzają racje podmiotu obowiązanego z tytułu podatku, natomiast w danej sytuacji sa niedostępne dla organu podatkowego. W ten sposób podmiot obowiązany z tytułu podatku, korzystając z ochrony wynikającej z domniemań będących konsekwencją złożenia deklaracji podatkowej, może dobrowolnie wesprzeć organ w ustalaniu prawdy materialnej. Co do zasady oczekiwanie przez administrację podatkową takiej postawy od podatnika nie ma natomiast podstaw prawnych.

Adam Nita

Uniwersytet Jagielloński

adam.nita@uj.edu.pl

https://orcid.org/0000-0002-9554-4267

Brzeziński, B., Masternak, M. (2004). O tak zwanym ciężarze dowodu w postępowaniu podatkowym. Przegląd Podatkowy 5: 56-59.

Brzeziński, B. (2005). Deklaracja podatkowa - istota i charakter prawny. Prawo i Podatki 11.

Gelger, W. (1962). Domniemanie ważności aktu administracyjnego w Kodeksie postępowania administracyjnego. Ruch Prawniczy, Ekonomiczny i Socjologiczny 24(4): 41-62.

Grzybowski, S. (1985). Prawo cywilne. Zarys części ogólnej. Warszawa.

Hanusz, A. (2006). Podstawa faktyczna rozstrzygnięcia podatkowego. Kraków.

Jakimowicz, W. (2001). Publiczne prawa podmiotowe państwa. Państwo i Prawo 51(10): 49-63.

Jakimowicz, W. (2002). Publiczne prawa podmiotowe. Warszawa.

Jurewicz, A.R. (2009). Problem domniemania w rzymskim ius quod ad personas pertinet. Olsztyn.

Kunicki, A. (1969). Domniemania w prawie rzeczowym. Warszawa.

Mariański, A. (2009). Rozstrzyganie wątpliwości na korzyść podatnika. Zasada prawa podatkowego. Warszawa.

Mastalski, R. (2019). Prawo podatkowe. Warszawa.

Masternak-Kubiak, M. (2017). Prawo do grobu jako publiczne prawo podmiotowe. Wrocławsko-Lwowskie Zeszyty Prawnicze 8: 231-241.

Morawski, L. (1981). Domniemania a dowody prawnicze. Torun.

Morawski, W. (2009). Ulgi i zwolnienia podatkowe, [w:] B. Brzeziński (red.), Prawo podatkowe. Teoria, instytucje, funkcjonowanie. Toruń: 249-264.

Nita, A. (2007). Czynnik czasu w prawie podatkowym. Studium z dziedziny zobowiązań podatkowych. Gdańsk.

Nowacki, J. (1976). Domniemania prawne. Katowice.

Patryas, W. (2011). Próba wyjaśnienia domniemań prawnych. Poznań.

Tomaszewska, K. (2012). Znaczenie i zakres ochrony publicznych praw podmiotowych a ochrona interesu jednostki. Folia Iuridica Wratislaviensis 1: 113-134.

\section{THE PRESUMPTION OF THE CORRECTNESS OF A TAX RETURN AND ITS EVIDENTIAL SIGNIFICANCE}

\section{Summary}

Presumption is a legal construction known in diverse branches of law - both private and public law. However, one of the aspects connected with applications of this structure in tax law is the presumption of the truthfulness of the tax declaration. This is regulated in general tax law (in the Tax Ordinance) and in special tax law (for example in the VAT law act). In making it a legal presumption, the legislator assumes the truthfulness of all the data which make up the content of the tax declaration submitted by a taxpayer. This concerns both declarations which only inform the tax administration about the tax base of a particular person, as well as declarations which include a so-called self-assessment, made by a taxpayer. The author considers the essence of 
presumption as a legal construction, the reason for such a regulation in the tax law, and presents its consequences. In the opinion of the author, one outcome is that the burden of proof principally falls on the tax authorities which impugn the tax declaration. It concerns all of elements of chargeable event, the fulfilment of which by a taxpayer creates the tax obligation. Therefore, the author is an opponent of dividing the burden of proof in tax law. According to this idea, some elements of tax event that are beneficial for a tax debtor, because they reduce the amount of tax (for example, costs in income tax, tax relief or input tax in value added tax) should be proven by a taxpayer. However, improving of other parts of the chargeable event would be the duty of the tax authorities.

Keywords: presumption; burden of proof in tax law 